\title{
Inquiry-Based Learning in the Engineering Sciences
}

\author{
Thorsten Jungmann
}

Creativity and a capacity for innovation are among the intended learning outcomes in Engineering Education. Engineers are expected to develop technical solutions for current and future technical and social problems. Inquiry-based learning as a didactic principle can be used to design the teaching-learning environments in such a way that, in addition to professional competencies, students can learn critical interdisciplinary competencies as well. Based on the research of Johannes Wildt, Ralf Schneider and Thorsten Jungmann (cf. Schneider and Wildt 2009, Ossenberg and Jungmann 2013), a research workshop for engineering students was developed and set up at the Technical University of Dortmund. The newly designed format and, above all, the special set-up and equipment on site are intended to close the gap between theoretical knowledge acquisition and practical engineering work.

\subsection{Creativity and Innovation Cannot Be Learned by Rote Memorization}

Engineers are creative problem-solvers. Their developments have an impact on people, society and the environment. Large development projects are handled by interdisciplinary teams, the members of which must have more than professional methodological engineering skills alone. In addition to creative problem-solvers, engineers who work using

T. Jungmann, Prof. Dr.-Ing. ( $\square)$

Jungmann Institut, Herne, und Fachhochschule Bielefeld, Fachbereich Ingenieurwissenschaften und Mathematik, Professur für Ingenieurwissenschaftliche Grundlagen und Technikdidaktik, Bielefeld, Germany

e-mail: tj@jungmann-institut.de

H. A. Mieg (ed.), Inquiry-Based Learning - Undergraduate Research, https://doi.org/10.1007/978-3-030-14223-0_19 
analytical calculation are also needed. Consequently, engineers should be able to generate creative, innovative ideas as well as transform their ideas into technically feasible, safe and sustainable solutions using the analytical methods of engineering sciences. It is not just fully trained engineers who are subject to a variety of requirements. At the start of a degree program in engineering, students are often already faced with conflicting expectations: "short periods of study, study abroad, soft skills, economic skills and, on top of that, good grades in the core engineering subjects" (Becker 2007, p. 1, translated).

A survey of career beginners conducted by Karl-Heinz Minks (cf. 2004, p. 34) brought to light the fact that, at the start of a career in engineering, the following abilities are especially decisive: working independently, communicating with others, organizing oneself and others, and assuming responsibility for processes and products. Engineering education is usually characterized by lectures and tutorials in the first few semesters, the primary goal of which is to impart basic professional knowledge to the students. In later semesters, the lecture format is then supplemented by laboratory- and project work. Experiments frequently take place in labs with guidance, with the findings already known in advance. The effect here is frequently reproduction rather than creativity.

The conflict of objectives in Engineering Education is training engineers to be scientists on the one hand, but also preparing them for the creative and engineering-related solution of technical issues on the other. In view of this conflict, the development of a new teaching-learning format on the basis of inquiry-based learning is proving to be productive.

\subsubsection{Inquiry-Based Learning Fosters Creativity and a Capacity for Innovation}

In addition to the remarks by Ludwig Huber (2009) and the Federal University Assistants' Conference (BAK) (1970) on inquiry-based learning (cf. Mieg, Pasternack, Reiber, Huber, in this volume), the definition developed by Karin Reiber and Peter Tremp stresses the open, unfinished character of research:

Inquiry-based learning means an introduction into science through the medium of scientific reflection and forms of working. The skills of research are learned, as well as disciplinary knowledge. An attitude is practiced that is characteristic of scientific activities: wanting to know something, questioning a factual situation and one's own views at a critical distance. Inquiry-based learning can be characterized by the fact that the academic field is not treated as a finished and fixed education building and is not presented as a static possession of certain knowledge, but instead is developed through questions for which research seeks answers. (Reiber and Tremp 2007, translated)

As such, inquiry-based learning does not supplant the lecture as a teaching method. In addition to active, independent learning, receptive learning through a systematic or problem-related transfer of knowledge also has its place in teaching: "If there is a canon 
of knowledge capable of producing a consensus, this should be imparted during the overview" (Reinmann 2009, p. 42, translated). Examples of this include the rules for the execution of technical drawings as well as the process model of "systems engineering," which embeds the evaluation of the solution in the entire, systematically designed product development process. It is the understanding of such fundamental methods and their practiced application that allows the professional handling of creative ideas in the innovation process. Thus, for example, effective and professional communication about various solutions for a given technical problem is made possible by sketches and drafts completed in compliance with the rules for the execution of technical drawings.

Similarly, genetic and critical learning have their place in inquiry-based learning: Genetic learning or, in other words, the reproduction of research processes from the initial question to the result by students supersedes inquiry-based learning when the latter is too difficult, time-consuming or resource-intensive. Critical learning serves to reflect basic scientific questions and cognitive processes, to develop critical distance and to learn independent scientific work (ibid.).Gabi Reinmann (2009) advocates not viewing the problemoriented approach as a central characteristic of inquiry-based learning as do, in her view, "nearly all authors who are currently discussing inquiry-based learning." She advocates returning to the core characteristics of inquiry-based learning as conceived nearly 40 years ago in the Federal University Assistants' Conference (BAK), but in so doing, to not exclude the complimentary forms of learning (genetic, receptive and critical learning). According to Reinmann, inquiry-based learning is taking place when

[s]tudents conduct their own research (e.g. as a final paper) when they participate in a research project by taking on a single task (e.g. in the case of larger projects), when they perform research 'on a small scale,' thus research that is guided and for practice (education research within the context of courses) or when they are at least able to understand the research process (genetic learning). (Reinmann 2009, p. 43, translated)

Inquiry-based learning once again gained increased significance in the course of the Bologna Process. Based on the recommendations of the German Science Council (Wissenschaftsrat) (cf. Wissenschaftsrat 2001, p. 41) the use of inquiry-based learning for Engineering Education clearly demonstrated the following:

- The objective of a degree program in engineering to acquire (a) the competence needed to deal with typical problems and tasks in professional practice and (b) the disciplinary knowledge which leads to the ability to make judgments in a scholarly examination of the subject, and which incorporates reflective competence and professional know-how with reference to the professional field of engineers.

- Engineering Education should promote and foster an attitude of inquiry-based learning, in order to enable future engineers to utilize their theoretical knowledge to analyze and shape the professional field and, in this way, carry out their activities not in a manner that is remote from scholarly pursuits, but rather with a research-centric attitude. 


\subsubsection{Inquiry-Based Learning in Engineering Education}

How can inquiry-based learning be implemented in the engineering sciences? What could learning in the format of research look like in the engineering sciences? Synchronizing learning and research processes, as illustrated in Figure 19.1, shows us some of the possibilities.

The figure is based on the learning cycle according to Kolb (1984), which is shown inside. The outside of the figure models the sequence of activities typical for research projects in engineering.

The synchronized cycles start with the perception of a problem or a question. Curiosity can be the driving force both in the case of learning and in the case of researching. After the students have specified the problem and defined the system boundaries, the problem can be abstractly conceptualized or modeled. Immersion in the theory contributes to a conceptual understanding and supports both the development of a research question and the selection and establishment of a research methodology. The planning and implementation of the research project leads to activities such as experimentally checking the abstract concept or model, for example. When analyzing and interpreting the resulting data, students find out whether later concrete experiences with the research subject can be predicted using the abstract concept. Errors become apparent when the results are implemented

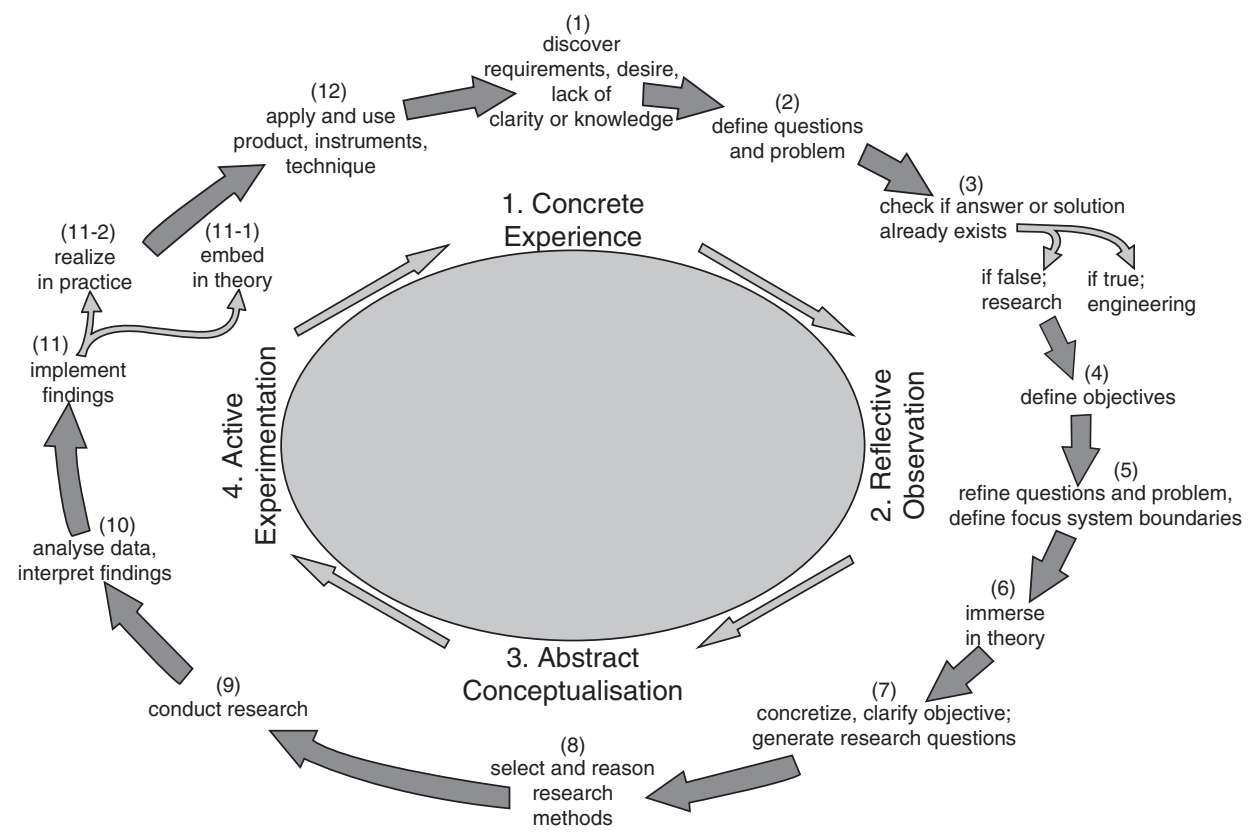

Fig. 19.1 The research cycle according to Jungmann (2011) synchronizes with the learning cycle according to Kolb (1984). (Source: author's representation) 
in practice or are embedded in theory. The cycle starts again as soon as ambiguity or new issues arise after the implementation.

Based on the classification system proposed by Huber (2013), we distinguish between inquiry-based learning in the narrower sense and inquiry-based learning in the broader sense. In the narrower sense, inquiry-based learning is the format as described by the Federal University Assistants' Conference (BAK) 1970, in which students go through the entire research cycle largely autonomously in terms of methodology and content, based on a subject of their own choosing. Inquiry-based learning in the broader sense is the umbrella term for various formats, for example research-oriented learning or research-based learning. In this broad sense, inquiry-based learning can be implemented in Engineering Education, for example by having the students:

- delimit a problem,

- determine a state of the art,

- select methods,

- establish a model,

- perform experiments,

- interpret results in the context of methods and theory and/or

- publish results.

Students participate in individual phases of the research process or in the entire research process. This flexibility in the implementation of inquiry-based learning makes it possible to design teaching-learning processes, which result in the desired increase in competence in the field of professional, methodological and interdisciplinary competencies.

\subsection{Where Does Inquiry-Based Learning Take Place in the Degree Program in Engineering?}

Inquiry-based learning in Engineering Education can occur in various locations. Lecture halls and seminar rooms offer good opportunities for students to participate in lectures on research (results) and impart the canon of knowledge capable of producing a consensus based on the state of scholarship. In laboratories, students can perform experiments on equipment and machines on an industrial scale. Students can learn to do research away from machinery and equipment in the research workshop, a learning site specifically set up for this purpose, and which will be discussed in greater detail later in this article. Here, they learn to develop a critical attitude, and to question and discuss their own research findings and those of other. Each of the following sections examines one of the various locations for inquiry-based learning. 


\subsubsection{Inquiry-Based Learning in a Seminar Room: Tutorial, "Kreativität und Technik" ("Creativity and Technology"), TU Berlin}

The technical realization of creative ideas in the course of construction is an essential element of research in mechanical engineering. In the tutorial, "Kreativität und Technik" ("Creativity and technology"), which is offered at TU Berlin within the context of their orientation studies, "MINTgruen" (MINTgreen) ${ }^{1}$, the fundamentals of engineering design are conveyed before the students apply them in their own work. One individual application is the design of a mechanical timepiece. Students independently design the form, select the material and define the function of their timepieces. In so doing, they chose a strategy in terms of the methods being applied, experimental design and research. They are confronted with the corresponding risk of resting on errors and taking detours, of working in a scientific manner and portraying the results in such a way that, the significance is clear and the way in which those results were reached is verifiable. They work in teams, and are supported by tutors. Here, creativity is especially important because both tried and true solutions and innovative approaches to solving the problem come into question and are weighed against each other.

This teaching-learning scenario must be categorized as inquiry-based learning in the narrower sense. It exhibits essential features of inquiry-based learning and introduces students to situations within the context of projects that are competently dealt with in research-oriented behavior.

\subsubsection{Inquiry-Based Learning in the Laboratory: Maastricht Science Programme, Maastricht University}

In the "Maastricht Science Programme," students can help to shape their bachelor's degree program according to their own abilities and inclinations. In addition to core modules such as biology, chemistry and physics, the course of studies even includes elective modules such as "biomedical engineering." Here, the students work on currently relevant, stillunanswered research questions. They carry out their own small research projects, working closely with scientists from the university. They perform experiments in labs within the context of their research projects, for example in thermogravimetric analysis or gas chromatographic mass spectrometry. They document their findings and present them to the interested public at technical conferences and in journals.

This teaching-learning scenario corresponds to inquiry-based learning in the narrower sense, whereby the emphasis here is on learning the skills of research when dealing with highly modern lab equipment on the one hand, and the comprehensible planning and documentation of experiments on the other.

\footnotetext{
${ }^{1}$ Translator's note: MINT is the German equivalent of the English STEM.
} 


\subsubsection{The Dortmund Research Workshop for Engineering Students}

In designing the research workshop described here, the focus was on motivation, effectively supporting the engineering students in their professional and personal development; special emphasis was placed on the development of creativity and a capacity for innovation that cannot be trained in a lecture hall or in specialist laboratory. Based on the didactic principle of inquiry-based learning, the research workshop for engineering students was designed as a teaching-learning environment in which students were trained to become innovative problem-solvers. The focus is on producing the aforementioned learning situations and occasions, thereby facilitating and promoting their own interest-based engagement with a topic from a research perspective. Subject areas include Industry 4.0, mobility concepts in megacities and resource efficiency in production technology.

In the standard spatial configuration (see Figure 19.2), the research workshop is divided into two areas that can be flexibly separated from one another. In the part of the research workshop shown on the left, students can work and discuss in groups, develop ideas for their own research projects or immerse themselves in literature. Moderation, research and visualization tools $(1,2)$ as well as literature $(8)$ are thereby made available to them. The right part, which is delimited from the left by flexible partitions (2), is optimized for presentations and equipped with presentation media $(6,7)$. It is designed such that students can present the results of their research activity.

The Dortmund research workshop for engineering students is an activity that is part of the "Exzellentes Lehren und Lernen in den Ingenieurwissenschaften" (ELLI) ("Excellent teaching and learning in the engineering sciences") project funded by the Bundesministerium

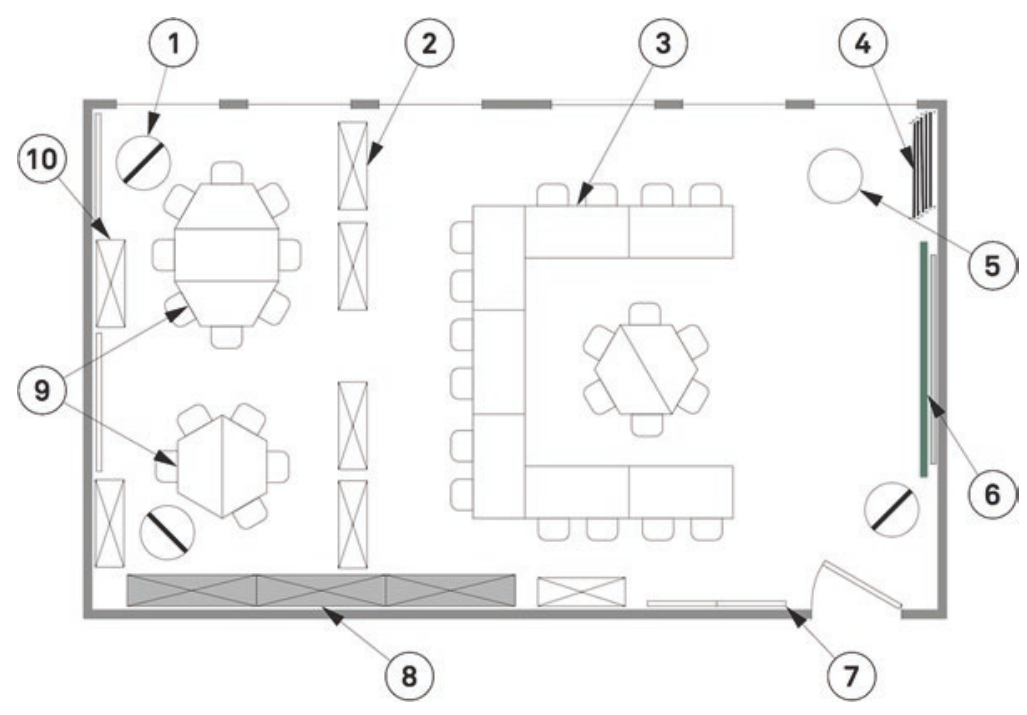

Fig. 19.2 Floorplan of the research workshop for engineering students at the TU Dortmund campus according to Jungmann und Ossenberg 2014. (Source: author's representation) 
für Bildung und Forschung, within the context of which inquiry-based learning plays a prominent rule due to its special suitability for teaching in a manner that fosters innovation and creativity. With the ELLI project, the three project partners - RWTH Aachen, Ruhr University Bochum and Technical University of Dortmund - have taken on the task of effectively improving Engineering Education at their locations. The team at the research workshop is comprised of experienced scientists, academic staff and student assistants, who together design the various courses and make them accessible to students. At the Dortmund research workshop, there is a special task for student assistants who have a tutoring qualification, and who support students in their learning and working phases in inquiry-based learning.

\subsubsection{Courses at the Research Workshop}

The team at the research workshop and the materials provided support inquiry-based learning in the engineering sciences during free hours of operation, workshops, courses and experimental workshops.

During the hours of operation, students are free to use the research workshop. They have the opportunity to use the materials available in the research workshop - which include the experimentation sets or the moderation and presentation technology - for their own "research projects" (e.g. their bachelor's thesis) either individually or in small groups, or practice their next presentation. Furthermore, the students can seek advice from the tutors on scientific work during the hours of operation. The goal is for students to already start using the research workshop during the first semesters of their studies so that they can familiarize themselves with independent work on exciting topics early on while using a scientific methodology.

In addition to the hours of operation, the research workshop provides students with the opportunity to develop and refine key qualifications in workshops. Workshop topics include time and self-management, presentation techniques and scientific work. Depending on the topic, the workshops at the research workshop last between three hours and two full days. Students from the engineering sciences as well as other departments participate in the workshops. The resulting interdisciplinary perspectives on the workshop topics can be used beneficially, especially in inquiry-based learning processes. The workshops encourage students to engage in active and sustainable learning. Learned methods can be tried out immediately and then evaluated.

In addition to the workshops, which are self-contained, short thematic sections of the research cycle, the course, "Fit for Science - Wissenschaftliches Arbeiten in den Ingenieurwissenschaften mit Tablet-PCs organisieren und präsentieren" ("Fit for Science organizing and presenting scientific work in the engineering sciences using tablet PCs" 
cf. May and Ossenberg 2015), has been established as part of the Dortmund research workshop. Students go through the entire research cycle in groups during the course. Collaborative scientific work is supported by mobile devices. Mobile devices particularly support the informal learning processes, for example using Evernote and other apps directed towards collaboration and productivity. They allow students to work on their topics across various platforms outside of their university courses and provide the opportunity to document not only the results of the informal learning processes but also the progression thereof in a comprehensible manner.

Experiments are frequently used in the engineering sciences. Research questions are answered empirically or data relevant to finding a solution is identified with the help of experiments. The significant step of experiment planning precedes the task of actually conducting the experiment. As a rule, the complexity of a problem or question is reduced by means of abstraction and idealization, as well as by appropriate assumptions, so that these can be examined in the experiment. The innovative teaching-learning format "FLExperiment" was developed in order to enable the students to acquire the skills needed to do so. Various experimentation sets, which are available in the research workshop, allow students to get their first experiences with technical experiments without having to rely on the availability of laboratory equipment. FLExperiments allow students to plan and conduct experiments without expensive lab equipment. By doing so, the students learn to hypothesize and confirm or disprove by conducting experiments. They practice writing a scientific report documenting their experiment, including the experimental setup, methods, materials used, research results and conclusions.

After conducting several FLExperiments in experimentation workshops, students will have acquired the basic skills necessary to plan, perform and evaluate experiments. In the further course of their learning, tutorial support for the researching learning processes replaces the methodical guidance. Peer-learning and peer-review are initiated and fostered. Students work on parts of the research cycle during the early stages of the FLExperiments. As learning progresses, there is a transition from partial processing to going through the entire research cycle.

\subsection{Summary and Outlook}

Inquiry-based learning as a didactic principle can be used to design the teaching-learning environments in such a way that, in addition to professional competencies, students can learn critical interdisciplinary competencies as well, especially in the engineering sciences. Its special suitability for competency-oriented, student-centered and, at the same time, science-related degree program design makes inquiry-based learning a preferred didactic principle in engineering programs, especially as there are numerous points of contact for inquiry-based learning, e.g. laboratory internships and experimental lectures. 
There are challenges posed by the practical implementation of inquiry-based learning, especially in terms of curricular embedding or, respectively, in assigning credits for the student workload. In particular, it is necessary to consider the special organized and informal learning processes when calculating and awarding credit points.

\section{References}

Becker, F. S. (2007). Was heute von Ingenieuren verlangt wird. Markttrends, Erfahrungen von Berufsanfängern, Erwartungen von Personalverantwortlichen und Karrieremechanismen. In J. Grüneberg/I. G. Wenke (Hrsg.), Arbeitsmarkt Elektrotechnik Informationstechnik 2007 (S. 13-32). Berlin: VDE-Verlag.

Bundesassistentenkonferenz (BAK) (1970). Forschendes Lernen - Wissenschaftliches Prüfen. Bd. 5. Bonn: Schriften der Bundesassistentenkonferenz.

Huber, L. (2009). Warum Forschendes Lernen nötig und möglich ist. In L. Huber, J. Hellmer/ F. Schneider (Hrsg.), Forschendes Lernen im Studium (S. 9-35). Bielefeld: Universitäts VerlagWebler.

Huber, L. (2013, 02. September). Forschendes Lernen: Forschungs- und Entwicklungsaufgaben [Eigene Mitschrift]. Vortrag an der FH Potsdam, Potsdam.

Jungmann, T. (2011). Forschendes Lernen im Logistikstudium: Systematische Entwicklung, Implementierung und empirische Evaluation eines hochschuldidaktischen Modells am Beispiel des Projektmanagements [Dissertation]. TU Dortmund, Deutschland.

Jungmann, T./Ossenberg, P. (2014). Research Workshop in Engineering Education: Draft of new Learning. In Proceedings of the 2015 IEEE Global Engineering Education Conference $(E D U C O N)$. Konferenzbericht der Engineering Education towards Excellence and Innovation, Tallinn University of Technology, Tallinn, Estland (S. 83-87).

Kolb, D. A. (1984). Experiential learning: experience as the source of learning and development. Englewood Cliff NJ: Prentice Hall.

May, D./Ossenberg, P. (2015, März). Fit for Science: A course for teaching to organize, perform and present scientific work with mobile devices. In Proceedings of the 2015 IEEE Global Engineering Education Conference (EDUCON). Konferenzbericht der Engineering Education towards Excellence and Innovation, Tallinn University of Technology, Tallinn, Estland (S. 176-183).

Minks, K.-H. (2004). Kompetenzen für den Arbeitsmarkt: Was wird vermittelt, was vermisst? In Stifterverband für die Deutsche Wissenschaft e.V. (Hrsg.), Bachelor- und Masteringenieure. Welche Kompetenzen verlangt der Arbeitsmarkt? Positionen (S. 32-40). Essen: Stifterverband für die Deutsche Wissenschaft e.V.

Ossenberg, P./Jungmann, T. (2013). Experimentation in a Research Workshop: A Peer-learning Approach as a First Step to Scientific Competence. International Journal of Engineering Pedagogy (iJEP), 3 (2013), 27-31.

Reiber, K./Tremp, P. (2007). Eulen nach Athen! Forschendes Lernen als Bildungsprinzip. In B. Berendt/H.-P. Voss/J. Wildt (Hrsg.), Neues Handbuch Hochschullehre. Lehren und Lernen effizient gestalten. [Teil] A. Lehren und Lernen. Neue Lehr- und Lernkonzepte. (Griffmarke A 3.6). Berlin: Raabe.

Reinmann, G. (2009). Wie praktisch ist die Universität? Vom situierten zum Forschenden Lernen mit digitalen Medien. In L. Huber/J. Hellmer/F. Schneider (Hrsg.), Forschendes Lernen im Studium. Aktuelle Konzepte und Erfahrungen. Bd. 10. Motivierendes Lehren und Lernen in Hochschulen (S. 36-52). Bielefeld: UniversitätsVerlagWebler. 
Schneider, R./Wildt, J. (2009). Forschendes Lernen und Kompetenzentwicklung. In L. Huber /J. Hellmer/F. Schneider (Hrsg.), Forschendes Lernen im Studium. Aktuelle Konzepte und Erfahrungen. Bd. 10. Motivierendes Lehren und Lernen in Hochschulen (S. 53-69.) Bielefeld: Universitäts VerlagWebler.

Wissenschaftsrat (2001). Empfehlungen zur künftigen Struktur der Lehrerbildung. Berlin: Wissenschaftsrat.

Open Access This chapter is licensed under the terms of the Creative Commons AttributionNonCommercial-NoDerivatives 4.0 International License (http://creativecommons.org/licenses/bync-nd/4.0/), which permits any noncommercial use, sharing, distribution and reproduction in any medium or format, as long as you give appropriate credit to the original author(s) and the source, provide a link to the Creative Commons licence and indicate if you modified the licensed material. You do not have permission under this license to share adapted material derived from this chapter or parts of it.

The images or other third party material in this chapter are included in the chapter's Creative Commons licence, unless indicated otherwise in a credit line to the material. If material is not included in the chapter's Creative Commons licence and your intended use is not permitted by statutory regulation or exceeds the permitted use, you will need to obtain permission directly from the copyright holder.

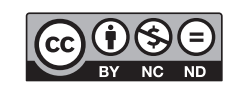

